\title{
PENGARUH PUPUK KASCING DAN NPK MUTIARA 16:16:16 TERHADAP PERTUMBUHAN SERTA HASIL TANAMAN SELEDRI (Apium graviolens L.)
}

\author{
Effects of Vermicompost and NPK Pearl 16:16:16 on the Growth and Yield of Celery Plants \\ (Apium graviolens L.)
}

\author{
Yurnie Sari Alphiani, Zulkifli, Sulhaswardi \\ Jurusan Agroteknologi, Fakultas Pertanian, Universitas Islam Riau \\ Jalan Kaharuddin Nasution No. 113, Marpoyan, Pekanbaru, Riau 28284 \\ Email : yurniesari@student.uir.ac.id \\ [Diterima: Desember 2018; Disetujui: Desember 2018]
}

\begin{abstract}
The purpose of this study is to determine the effect of interaction and the main influence of vermicompost and NPK Pearl 16:16:16 on the growth and yield of celery plants. This research was carried out for four months, from August to November 2018. This research used a factorial completely randomized design (RAL) consisting of two factors, where the first factor was vermicompost fertilizer (K) consisting of 4 levels, namely $0,60,80,100 \mathrm{~g} /$ polybag and the second factor is NPK Pearl 16:16:16 (N) fertilizer consisting of 4 levels, 0, 0.8, 1.6, $2.4 \mathrm{~g} /$ polybag. The observation parameters in this study were plant height $(\mathrm{cm})$, relative growth rate $(\mathrm{g})$, root volume (cm3), number of tillers, number of midribs, wet weight of crop (g), and age of harvest (days). The last observation data were statistically analyzed and continued with a BNJ follow-up test at the 5\% level. The results showed that the interaction between vermicompost and NPK Pearl 16:16:16 fertilizer significantly affected plant height from week two to week seven, the relative growth rate in the first week, root volume, number of tillers, number of fronds and wet weight per plant. The best treatment is $\mathrm{K} 3 \mathrm{~N} 3$ (K3 vermicompost fertilizer $=100 \mathrm{~g}$ /polybag and NPK Pearl 16:16:16 N3 = 2,4 $\mathrm{g} /$ polybag), but it has no significant effect on the age of harvest and the main effect of vermicompost and NPK Pearl 16:16: 16 significantly affected plant height, relative growth rate, root volume, number of tillers, number of midribs and wet weight of the crop, with the best treatment being K3 (vermicompost fertilizer $100 \mathrm{~g} /$ polybag) and N3 (NPK Pearl 16:16:16 2,4 g/polybag).
\end{abstract}

Keywords: Celery, Vermicompost, NPK pearl 16:16:16

\begin{abstract}
ABSTRAK
Tujuan penelitian yaitu untuk mengetahui pengaruh interaksi dan pengaruh utama pupuk Kascing serta NPK Mutiara 16:16:16 terhadap pertumbuhan dan hasil tanaman seledri. Penelitian ini dilaksanakan selama empat bulan, mulai bulan Agustus sampai dengan November 2018. Penelitian ini menggunakan rancangan acak lengkap (RAL) Faktorial yang terdiri dari dua faktor, dimana faktor pertama yaitu pupuk Kascing (K) yang terdiri dari 4 taraf yaitu $0,60,80,100 \mathrm{~g} /$ polybag dan faktor ke dua yaitu pupuk NPK Mutiara 16:16:16 (N) yang terdiri dari 4 taraf yaitu 0, 0,8, 1,6, 2,4 g/polybag, sehingga didapat 16 kombinasi perlakuan. Parameter pengamatan dalam penelitian ini yaitu tinggi tanaman $(\mathrm{cm})$, laju pertumbuhan relatif $(\mathrm{g})$, volume akar $\left(\mathrm{cm}^{3}\right)$, jumlah anakan, jumlah pelepah, berat basah pertanaman (g) serta umur panen (hari). Data pengamatan terakhir dianalisis secara statistik dan dilanjutkan dengan uji lanjut BNJ pada taraf $5 \%$. Hasil penelitian menunjukkan bahwa secara interaksi pupuk Kascing dan NPK Mutiara 16:16:16 memberikan pengaruh nyata terhadap tinggi tanaman dari minggu ke dua sampai minggu ke tujuh, laju pertumbuhan relatif pada minggu pertama, volume akar, jumlah anakan, jumlah pelepah dan berat basah per tanaman. Perlakuan terbaik adalah K3N3 (pupuk Kascing K3 = 100 g/polybag dan NPK Mutiara 16:16:16 N3 $=2,4 \mathrm{~g} /$ polybag), namun tidak berpengaruh nyata terhadap umur panen dan pengaruh utama pupuk Kascing maupun NPK Mutiara 16:16:16 berpengaruh nyata terhadap tinggi tanaman, laju pertumbuhan relatif, volume akar, jumlah anakan, jumlah pelepah dan berat basah pertanaman,
\end{abstract}


dengan perlakuan terbaik adalah K3 (pupuk Kascing 100 g/polybag) dan N3 ( NPK Mutiara 16:16:16 $2,4 \mathrm{~g} /$ polybag).

Kata kunci : Seledri, Pupuk kascing, NPK mutiara 16:16:16

\section{PENDAHULUAN}

Seledri (Apium graviolens L.) adalah tanaman sayuran bumbu berbentuk rumput yang berasal dari benua Amerika. Seledri termasuk dalam familyUmbelliferae dan merupakan sayuran yang banyak disukai dan dibutuhkan masyarakat sebagai obat tradisional, penyedap makanan dan penghias hidangan dengan ciri khas sebagai penambah aroma hidangan. Seledri dapat tumbuh pada dataran rendah sampai tinggi dan optimal pada ketinggian tempat 1.000-1.200 $\mathrm{m}$ diatas permukaan laut. Tanaman seledri juga dapat dikembangkan pada daerah tropis seperti di Indonesia. Menurut Departemen Kesehatan RI (2000), setiap 100 gram daun seledri mengandung protein 0,9 gram, lemak 0,1 gram, karbohidrat 4 gram, serat 0,9 gram, kalsium 50 $\mathrm{mg}$, besi $1 \mathrm{mg}$, iodium $150 \mathrm{mg}$, kalium $400 \mathrm{mg}$, magnesium $85 \mathrm{mg}$, vitamin A $130 \mathrm{IU}$, vitamin C $15 \mathrm{mg}$, riboflavin $0,05 \mathrm{mg}$, tiamin $0,03 \mathrm{mg}$ dan nikotinamid $0,4 \mathrm{mg}$.

Akar seledri berkhasiat untuk peluruh kencing dan memacu enzim pencernaan. Biji dan buahnya berkhasiat untuk pereda kejang, menurunkan asam urat, anti rematik, perangsang nafsu makan dan penenang. Sedangkan herba seledri berkhasiat untuk pereda kejang, menurunkan kadar gula darah, mengobati sakit ginjal, pembersih darah, memperbaiki fungsi hormon, selain itu seledri juga mampu menurunkan tekanan darah tinggi, serta dapat mengobati kerontokan rambut (Dalimartha,2000).

Banyaknya manfaat dan kegunaan seledri menyebabkan peluang usaha budidaya sangat berpotensi besar terutama dalam meningkatkan pendapatan dan memenuhi permintaan masyarakat yang terus meningkat. Nilai ekonomis tanaman seledri terletak pada bagian batang dan daunnya. Namun untuk di Riau kendala yang terjadi dalam pengembangan budidaya tanaman seledri adalah kondisi lingkungan yang kurang mendukung seperti cara budidaya, ketinggian tempat, unsur hara yang rendah, kelembapan tanah yang rendah, curah hujan yang tidak menentu dan suhu udara yang tinggi mengakibatkan pertumbuhan tanaman seledri kurang memuaskan baik dari segi kualitas maupun kuantitas bila dibandingkan di daerah Sumatra Utara dan Sumatra Barat. Hal inilah yang menjadi alasan rendahnya minat para petani untuk membudidayakan seledri. Akan tetapi, pada umumnyapetani di Riau masih membudidayakan tanaman seledrinamundalam skala kecil ataukomoditas pengganti dan tanaman sampingan sebagai upaya pemanfaatan lahan bukan komoditas utama. Seledri perlu mendapatkan suplai unsur hara yang cukup selama pertumbuhannya agar menghasilkan produktivitas yang tinggi dan berkualitas.

Diperlukan upaya menciptakan kesesuaian suhu, temperatur dan kelembapan lahan budidaya dengan syarat tumbuh tanaman seledri sehingga mampu mendukung proses pertumbuhan dan perkembangan seledri secara maksimal. Salah satu alternatif yang bisa dilakukan adalah dengan menggunakan pupuk yang berasal dari sumberdaya lokal di sekitar. Hal ini didukung oleh Nugroho (2004).

Kascing merupakan bahan organik yang mengandung unsur hara yang lengkap, baik unsur makro maupun unsur mikro yang berguna bagi pertumbuhan tanaman. Kompoisi kascing meliputi $\mathrm{N} 0.63 \%, \mathrm{P} 0.35 \%, \mathrm{~K} 0.20 \%$, Ca $0.23 \%, \mathrm{Mg} 0.26 \%, \mathrm{Na} 0.07 \%, \mathrm{Cu} 17.58 \%, \mathrm{Zn}$ $0.007 \%$, Mn $0,003 \%$, Fe $0.790 \%$, B $0.210 \%$, Mo $14.48 \%$, KTK $35.80 \mathrm{meg} / 100$ gram dan asam humus $13.88 \%$. disamping itu, kascing memiliki kandungan hormon pengatur tumbuh seperti auksin, giberillin, sitokinin dan memiliki kandungan bakteri Azotobakter.sp yaitu bakteri penambat $\mathrm{N}$ bebas di udara (Mulat, 2003).

Ditinjau dari unsur hara yang terkandung didalamnya, kualitas pupuk kascing ini menyerupai pupuk anorganik. Bila dilihat dari kelengkapan unsur haranya pupuk ini jauh lebih baik, karena hampir seluruh unsur hara yang diperlukan tanaman tersedia dan memiliki kandungan hormon tumbuh yang dapat memaksimalkan pertumbuhan dan hasil tanaman (Sutikno, 2009).

Selain dengan pemberian pupuk kascing, pemupukan juga dilakukan dengan pemberian 
pupuk Anorganik yaitu pupuk NPK 16:16:16. Merupakan salah satu jenis pupuk majemuk yang mengandung unsur hara $\mathrm{N} 16 \%, \mathrm{P} 16 \%, \mathrm{~K}$ $16 \%$ yang dibutuhkan tanaman walaupun hanya dalam jumlah yang relatif sedikit. Sehingga memudahkan aplikasi baik sebagai pupuk dasar maupun pupuk susulan pada tanaman (Anonimus, 2000).

Adapun tujuan dari pemupukan ialah memperbaiki stuktur tanah yang kurang baik, memperbaiki drainase dan sirkulasi udara dalam tanah, serta memperbaiki komponen fisik dan kimia tanah agar sesuai dengan kebutuhan tanaman, baik unsur hara makro dan mikro yang berperan dalam pertumbuhan Vegetatif dan Generatif tanaman.

Berdasarkan uraian diatas, penulis telah melakukan penelitian dengan judul "Pengaruh Pemberian Pupuk Kascing dan NPK Mutiara 16:16:16 terhadap Pertumbuhan serta Hasil Tanaman Seledri (Apium graviolens L.)".

Tujuan dari penelitian ini adalah untuk mengetahui pengaruh interaksi dan pengaruh utama pemberian Pupuk Kascing dan Pupuk NPK mutiara 16:16:16 terhadap pertumbuhan serta produksi tanaman seledri.

\section{BAHAN DAN METODE}

Penelitian ini telah dilaksanakan di kebun percobaan Fakultas Pertanian Universitas Islam Riau, Jalan Kaharuddin Nasution Km 11 No.113, Kelurahan Air Dingin, Kecamatan Bukit Raya, Kota Pekanbaru. Penelitian dilaksanakan selama 4 bulan, mulai bulan Agustus sampai dengan November 2018.

Bahan yang digunakan dalam penelitian ini adalah benih seledri Varietas Amigo Cap Panah Merah, pupuk Kascing, pupuk NPK Mutiara 16:16:16, furadan 3G, polybag ukuran 35 x $45 \mathrm{~cm}$, Dithane M-45 WP, Decis 25 EC, plat seng, ajir ukuran $5 \mathrm{~cm}$, kayu, tali, paku, plastik dan cat. Sedangkan alat yang digunakan dalam penelitian ini adalah cangkul, parang, gaharu, ember, meteran, gembor, timbangan analitik, timbangan biasa, selang, handsprayer, martil, kamera, alat tulis dan lain-lain.

Penelitian ini menggunakan Rancang Acak Lengkap (RAL) Faktorial yang terdiri dari 2 faktor, dimana factorpertama yaitu pupuk kascing (K) yang terdiri dari 4 taraf dan faktor kedua yaitu pupuk NPK Mutiara 16:16:16 (N) terdiri dari 4 taraf sehingga didapat 16 kombinasi perlakuan. Setiap kombinasi perlakuan diulang sebanyak 3 kali sehingga total keseluruhan 48 satuan percobaan. Setiap satuan percobaan terdiri dari 4 polybag dan 2 diantaranya dijadikan sampel, sehingga diperoleh total keseluruhan adalah 192 tanaman.

Parameter pengamatan yang dilakukan meliputi tinggi tanaman, laju pertumbuhan relatif, volume akar, jumlah anakan, jumlah pelepah, berat basah per tanaman dan umur panen. Data hasil pengamatan dari masingmasing perlakuan dianalisa secara statistik. Apabila $\mathrm{F}$ hitung lebih besar dari $\mathrm{F}$ tabel maka dilanjutkan dengan uji lanjut beda nyata jujur (BNJ) pada taraf $5 \%$.

\section{HASIL DAN PEMBAHASAN}

\section{Tinggi Tanaman $(\mathrm{cm})$}

Hasil pengamatan terhadap tinggi tanaman seledri setelah dilakukan analisis sidik ragam menunjukkan bahwa pengaruh interaksi maupun pengaruh utama pemberian pupuk Kascing dan NPK Mutiara 16:16:16 memberikan pengaruh nyata terhadap tinggi tanaman seledri. Rerata hasil pengamatan tinggi tanaman setelah dilakukan uji beda nyata jujur (BNJ) pada taraf 5\% dapat dilihat pada tabel 1 .

Berdasarkan data pada tabel 1, menunjukkan bahwa secara interaksi pemberian Pupuk Kascing dan NPK Mutiara 16:16:16 berpengaruh nyata terhadap tinggi tanaman pada umur 49 HST, tanaman tertinggi terdapat pada perlakuan K3N3 yaitu $33,72 \mathrm{~cm}$ tidak berbeda nyata dengan perlakuan K2N3 namun berbeda nyata dengan perlakuan lainnya dimana tinggi tanama terendah terdapat pada perlakuan K0N0 yaitu $17,87 \mathrm{~cm}$ yang tidak berbeda nyata dengan K1N0 25,18 cm, K2N0 25,90 cm dan K3N0 25,28 cm dan K3N1 27,13 cm.

Kandungan hara dalam kascing yang digunakan cukup tinggi yaitu $\mathrm{N}$ total $1,01 \%$, $\mathrm{P} 2 \mathrm{O} 52,83 \%$. dan $\mathrm{K} 2 \mathrm{O} \quad 0,82 \%$. Menurut Sutanto (2002) jenis kascing yang paling efisien dalam pembuatan kascing Eisenia Fetida dan Eisenia Eugeniae yang mampu menghasilkan N total $1,4-2,2 \%$, K2O 1,6-2,1\% dan P2O5 0,6$0,7 \%$. 
Tabel 1. Rerata tinggi tanam tanaman seledri pada pemberian pupuk Kascing dan NPK Mutiara 16:16:16 (cm)

\begin{tabular}{cccccc}
\hline Pupuk & \multicolumn{3}{c}{ Pupuk NPK Mutiara $16: 16: 16$ (g/tanaman) } & \multirow{2}{*}{ Rerata } \\
\cline { 2 - 5 } Kascing & N0 & N1 1 & N2 & N3 & \\
\hline K0 & $25,00 \mathrm{e}$ & $27,35 \mathrm{~d}$ & $27,22 \mathrm{de}$ & $30,42 \mathrm{~b}$ & $27,50 \mathrm{c}$ \\
K1 & $25,18 \mathrm{e}$ & $27,87 \mathrm{~cd}$ & $28,42 \mathrm{~cd}$ & $31,37 \mathrm{~b}$ & $28,21 \mathrm{~b}$ \\
K2 & $25,90 \mathrm{e}$ & $28,12 \mathrm{~cd}$ & $29,03 \mathrm{c}$ & $33,27 \mathrm{a}$ & $29,08 \mathrm{ab}$ \\
K3 & $25,28 \mathrm{e}$ & $27,13 \mathrm{de}$ & $31,80 \mathrm{~b}$ & $33,72 \mathrm{a}$ & $29,48 \mathrm{a}$ \\
\hline Rerata & $25,34 \mathrm{~d}$ & $27,62 \mathrm{c}$ & $29,12 \mathrm{~b}$ & $32,19 \mathrm{a}$ & \\
\hline KK $=2,20 \%$ & \multicolumn{3}{c}{ BNJ KN $=1,39$} & BNJ K \& N $=0,70$ &
\end{tabular}

Angka-angka pada baris dan kolom yang diikuti oleh huruf kecil yang sama tidak berbeda nyata menurut uji lanjut $\mathrm{BNJ}$ pada taraf $5 \%$

Kandungan bahan organik $18,92 \%$ dapat meningkatkan bahan organik tanah dan memperbaiki kesuburan tanah. Selain itu $\mathrm{pH}$ kascing yang digunakan 6,8. Menurut Mulat (2003) $\mathrm{pH}$ kascing yang sudah matang adalah 6,5-6,8, sehingga penggunaan kascing tidak menimbulkan kemasaman tanah.

Hayati dkk (2010), menyatakan bahwa untuk pertumbuhan vegetatif diperlukan unsur nitrogen, fosfor dan kalium serta unsur hara lainnya dalam julah cukup dan seimbang. Agustina (2004), nitrogen berperan untuk mendukung pertumbuhan vegetatif. Fosfor berperan sebagai regulator pertumbuhan akar. Sementara kalium sebagai katalisator terutama dalam perombakan protein menjadi asam amino dan meningkatkan fotosintesis.

Kamaruzaman dan Hasibuan (2003), jika seluruh unsur hara yang diperlukan tanaman terpenuhi dengan baik dan seimbang maka akan terjadi peningkatan sistem perakaran, fotosintesis dan pertumbuhan vegetatif sehingga mampu memacu panjang sel batang untuk meningkatkan pertumbuhan tinggi tanaman secara optimal.

Susanto (2005),juga menyatakan bahwa pemberian pupuk organik yang dipadukan dengan pupuk anorganik dapat meningkatkan produktivitas tanah dan efisiensi penggunaan pupuk.Penggunaan pupuk organik yang secara terus menerus dalam rentang waktu tertentu akan menjadikan kualitas tanah lebih baik, dan tidak meninggalkan residu pada hasil tanaman sehingga aman bagi kesehatan manusia.

Setiap perlakuan memberikan pengaruh yang berbeda pada tinggi tanaman.Perbedaan tinggi tanaman disebabkan oleh kemampuan menyerap hara yang berbeda pada setiap tanaman. Semakin optimal konsentrasi pupuk yang diberikan maka akan lebih cepat meningkatkan perkembangan organ seperti akar, sehingga tanaman dapat menyerap lebih banyak hara dan air yang ada di tanah yang selanjutnya akan mempengaruhi tinggi tanaman bawang dayak. Akan tetapi, tanaman juga memiliki batas tertentu dalam menyerap hara. Lakitan (2003) mengatakan bahwa adanya perbedaan laju pertumbuhan dan aktifitas jaringan meristematik yang tidak sama menyebabkan perbedaan laju pembentukan organ yang tidak sama, seperti pembentukan pada organ daun, batang, umbi dan organ lainnya.

Unsur nitrogen sangat penting bagi tanaman karena unsur ini menyusun protein yang merupakan komponen aktif protoplasma. Disamping itu fospor berperan dalam proses respirasi, fotosintesis dan metabolisme tanaman. Unsur hara $\mathrm{N}$ merupakan unsur hara yang berfungsi dalam merangsang perkembangan dan pertumbuhan vegetatif tanaman. Pertumbuhan vegetatif tanaman berkaitan erat dengan tinggi tanaman, semakin baik ketersediaan hara $\mathrm{N}$ maka tinggi tanaman akan semakin optimal (Hasil, 2013).

Menurut Prasetya (2014), semakin meningkat dosis pupuk maka terjadi kenaikan pertumbuhan tinggi tanaman. Hal ini disebabkan bahwa dengan semakin dewasanya tanaman, maka sistem perakaran telah berkembang dengan baik dan lengkap, sehingga tanaman semakin mampu menyerap unsur hara dalam bentuk anion dan kation yang mengandung unsur $\mathrm{N}, \mathrm{P}$ dan $\mathrm{K}$ yang terdapat pada pupuk tersebut. Dengan banyaknya unsur hara yang dapat diserap oleh tanaman, maka pertumbuhan dan perkembangan tanaman semakin meningkat. Bila dosis pupuk ditingkatkan, maka ada kecenderungan 
peningkatan pertumbuhan vegetatif dan generatif tanaman sesuai dengan pendapat Sutedjo (2008), bahwa untuk pertumbuhan vegetatif dan generatif tanaman diperlukan unsur-unsur hara terutama $\mathrm{N}, \mathrm{P}$ dan $\mathrm{K}$.

\section{Laju Pertumbuhan Relatif (LPR)}

Hasil pegamatan terhadap laju pertumbuhan relatif tanaman pada umur 14, 21 dan 35 hst setelah dilakukan analisis ragam menunjukkan bahwa pengaruh interaksi maupun pengaruh interaksi maupun pengaruh interaksi maupun pengaruh utama pemberian pupuk Kascing dan NPK Mutiara 16:16:16 memberikan pengaruh nyata terhadap Laju Pertumbuhan Relatif seledri. Rerata hasil pengamatan Laju Pertumbuhan Relatif setelah dilakukan uji beda nyata jujur (BNJ) pada taraf $5 \%$ dapat dilihat pada Tabel 2.

Tabel 2. Rerata Laju Pertumbuhan Relatif tanaman Seledri dengan pemberian pupuk Kascing dan NPK Mutiara 16:16:16 (g)

\begin{tabular}{|c|c|c|c|c|c|c|}
\hline \multirow{2}{*}{ HST } & \multirow{2}{*}{$\begin{array}{c}\text { Pupuk } \\
\text { Kascing } \\
\text { (g/tanaman) }\end{array}$} & \multicolumn{4}{|c|}{ Pupuk NPK Mutiara 16:16:16 (g/tanaman) } & \multirow{2}{*}{ Rerata } \\
\hline & & No & N1 & $\mathrm{N} 2$ & N3 & \\
\hline \multirow{6}{*}{14} & $\mathrm{~K} 0$ & $0,07 \mathrm{c}$ & $0,06 \mathrm{c}$ & $0,08 \mathrm{c}$ & $0,09 \mathrm{c}$ & $0,07 \mathrm{~b}$ \\
\hline & $\mathrm{K} 1$ & $0,07 \mathrm{c}$ & $0,09 \mathrm{c}$ & $0,09 \mathrm{c}$ & $0,12 \mathrm{bc}$ & $0,09 \mathrm{~b}$ \\
\hline & $\mathrm{K} 2$ & $0,08 \mathrm{c}$ & $0,12 \mathrm{bc}$ & $0,14 \mathrm{~b}$ & $0,17 \mathrm{ab}$ & $0,13 \mathrm{a}$ \\
\hline & K3 & $0,07 \mathrm{c}$ & $0,10 \mathrm{c}$ & $0,16 \mathrm{~b}$ & $0,27 \mathrm{a}$ & $0,15 \mathrm{a}$ \\
\hline & Rerata & $0,07 \mathrm{c}$ & $0,09 \mathrm{c}$ & $0,12 \mathrm{~b}$ & $0,16 \mathrm{a}$ & \\
\hline & $\mathrm{KK}=24,80 \%$ & \multicolumn{4}{|c|}{ BNJ KN $=0,06 \quad$ BNJ $K \& N=0,03$} & \\
\hline \multirow{6}{*}{21} & $\mathrm{~K} 0$ & 0,25 & 0,24 & 0,20 & 0,27 & $0,24 \mathrm{c}$ \\
\hline & $\mathrm{K} 1$ & 0,24 & 0,25 & 0,28 & 0,32 & $0,27 \mathrm{c}$ \\
\hline & $\mathrm{K} 2$ & 0,32 & 0,40 & 0,36 & 0,37 & $0,36 \mathrm{~b}$ \\
\hline & K3 & 0,52 & 0,45 & 0,47 & 0,47 & $0,48 \mathrm{a}$ \\
\hline & Rerata & 0,33 & 0,34 & 0,33 & 0,36 & \\
\hline & $\mathrm{KK}=20,87 \%$ & \multicolumn{2}{|c|}{$\mathrm{BNJ} \mathrm{K}=0,08$} & & & \\
\hline \multirow{6}{*}{28} & K0 & 0,84 & 1,20 & 1,10 & 0,87 & $1,00 \mathrm{c}$ \\
\hline & K1 & 1,21 & 1,31 & 2,04 & 1,21 & $1,44 \mathrm{~b}$ \\
\hline & $\mathrm{K} 2$ & 1,56 & 1,96 & 1,59 & 1,79 & $1,72 \mathrm{ab}$ \\
\hline & K3 & 1,99 & 1,93 & 1,96 & 2,12 & $2,00 \mathrm{a}$ \\
\hline & Rerata & 1,40 & 1,60 & 1,67 & 1,50 & \\
\hline & $\mathrm{KK}=21,47 \%$ & \multicolumn{2}{|c|}{ BNJ K = 0,37 } & & & \\
\hline
\end{tabular}

Angka-angka pada baris dan kolom yang diikuti oleh huruf kecil yang sama tidak berbeda nyata menurut uji lanjut BNJ pada taraf $5 \%$

Berdasarkan data pada tabel 2, menunjukkan bahwa secara interaksi pemberian Pupuk Kascing dan NPK Mutiara 16:16:16 berpengaruh nyata terhadap laju pertumbuhan relatif pada umur $14 \mathrm{HST}$, dimana perlakuan terbaik K3N3 yaitu $0,27 \mathrm{~g}$ tidak berbeda nyata dengan perlakuan $\mathrm{K} 2 \mathrm{~N} 3$ namun berbeda nyata dengan perlakuan lainnya dimana perlakuan terendah terdapat pada K0N0 yaitu $0,07 \mathrm{~cm}$.

Sedangkan pada umur 21dan 28 HST menunjukkan bahwa secara utama pemberian pupuk Kascing berpengaruh nyata terhadap laju pertumbuhan relatif.Pada umur 21 HST perlakuan terbaik terdapat pada K3 yaitu $0,48 \mathrm{~g}$ yang berbeda nyata dengan perlakuan lainnya dan perlakuan terendah terdapat pada K0 yaitu
0,24 g. Selanjutnya pada umur 28 HST perlakuan terbaik terdapat pada K3 yaitu $2,00 \mathrm{~g}$ yang tidak berbeda nyata dengan perlakuan K2 namun berbeda nyat dengan perlakuan lainnya dan perlakuan terendah terdapat pada perlakuan K0 yaitu 1,00 g.

Laju pertumbuhan relatif menunjukkan kemampuan tanaman untuk menumpuk bahan organik terakumulasi dalam tanaman (biomassa) yang meningkatkan berat. Pembentukkan biomassa tanaman meliputi semua bahan tanaman berasal dari fotosintesis dan hara serta air yang diolah dalam proses bosintesis (Salysbury dan Ross, 1996) menurut Gardneret et al. (1991), bahwa proses pertumbuhan mengarah pada akumulasi bobot berat kering dari tanaman dan proses itu akan 
terjadi apabila hasil asimilat cukup tersedia dan suhu yang menguntungkan. Pengukuran laju pertumbuhan tanaman juga dapat dilihat dari biomassa tanaman. Biomassa tanaman adalah masa bagian hidup tanaman. Biomassa tanaman merupakan parameter yang sangat sering digunakan untuk menggambarkan dan mempelajari pertumbuhan tanaman. Ini disebabkan atas kenyataan taksiran biomassa (berat) relatif mudah diukur dan merupakan integrasi dari hampir semua proses pertumbuhan tanaman. Pertumbuhan dapat diartikan sempit yaitu suatu pembelahan sel (peningkat jumlah) dan pembelahan (peningkatan ukuran). Kedua proses ini memerlukan sintesis protein dan merupakan proses yang tidak dapat terbalik.
Semakin tua umur tanaman maka laju pertumbuhan relatif semakin meningkat hal ini dikarenakan kebetuhan tanaman akan unsur hara semakin banyak dan mengakbatkan laju pertumuhan tanaman juga semakin meningkat.

\section{Volume akar $\left(\mathrm{cm}^{3}\right)$}

Hasil pengamatan terhadap volume akar seledri setelah dilakukan analisis sidik ragam menunjukkan bahwa pengaruh interaksi maupun pengaruh utama pemberian pupuk Kascing dan NPK Mutiara 16:16:16 memberikan pengaruh nyata terhadap volume akar seledri. Rerata hasil pengamatan volume akar setelah dilakukan uji beda nyata jujur (BNJ) pada taraf 5\% dapat dilihat pada tabel 3.

Tabel 3. Rerata volume akar tanaman seledri pada pemberian pupuk Kascing dan NPK Mutiara $16: 16: 16\left(\mathrm{~cm}^{3}\right)$

\begin{tabular}{cccccc}
\hline \multirow{2}{*}{ Perlakuan K } & \multicolumn{4}{c}{ Perlakuan N } & \multirow{2}{*}{ Rerata } \\
\cline { 2 - 4 } & $\mathrm{N} 0$ & $\mathrm{~N} 1$ & $\mathrm{~N} 2$ & $\mathrm{~N} 3$ & \\
\hline K0 & $8,83 \mathrm{~d}$ & $12,33 \mathrm{~cd}$ & $9,00 \mathrm{~d}$ & $11,67 \mathrm{~cd}$ & $10,46 \mathrm{c}$ \\
K1 & $15,00 \mathrm{~cd}$ & $14,33 \mathrm{~cd}$ & $13,00 \mathrm{~cd}$ & $15,50 \mathrm{~cd}$ & $14,46 \mathrm{~b}$ \\
K2 & $11,33 \mathrm{~cd}$ & $18,33 \mathrm{c}$ & $16,00 \mathrm{~cd}$ & $14,33 \mathrm{~cd}$ & $15,00 \mathrm{~b}$ \\
K3 & $22,17 \mathrm{bc}$ & $25,00 \mathrm{bc}$ & $26,67 \mathrm{~b}$ & $34,17 \mathrm{a}$ & $27,00 \mathrm{a}$ \\
\hline
\end{tabular}

\begin{tabular}{lllll}
\hline Rerata & $14,33 \mathrm{~b}$ & $17,50 \mathrm{ab}$ & $16,17 \mathrm{ab}$ & $18,92 \mathrm{a}$
\end{tabular}

$\mathrm{KK}=19,07 \% \quad \mathrm{BNJ} \mathrm{KN}=7,05 \quad \mathrm{BNJ} \mathrm{K} \& \mathrm{~N}=3,53$

Angka-angka pada baris dan kolom yang diikuti oleh huruf kecil yang sama tidak berbeda nyata menurut uji lanjut $\mathrm{BNJ}$ pada taraf $5 \%$

Berdasarkan data pada tabel 3, menunjukkan bahwa dimana interaksi pemberian pupuk Kascing dan NPK Mutiara 16:16:16 berpengaruh terhadap volume akar dimana kombinasi perlakuan K3N3 (Pupuk Kascing 100 g/polybag dan NPK Mutiara 16:16:16 2,4 g/polybag) tanaman memiliki volume akar tertinggi yaitu $34,17 \mathrm{~cm}^{3}$ yang berbeda nyata dengan kombinasi perlakuan lainnya. Sedangkan volume akar terendah terdapat pada kombinasi perlakuan KONO yaitu $8,83 \mathrm{~cm}^{3}$ yang tidak berbeda nyata dengan perlakuan K0N1 $12,33 \mathrm{~cm}^{3}, \mathrm{~K} 0 \mathrm{~N} 29,00 \mathrm{~cm}^{3}$, K0N3 $11,67 \mathrm{~cm}^{3}$, K1N0 $15,00 \mathrm{~cm}^{3}, \mathrm{~K} 1 \mathrm{~N} 1$ $14,33 \mathrm{~cm}^{3}, \mathrm{~K} 1 \mathrm{~N} 213,00 \mathrm{~cm}^{3}, \mathrm{~K} 1 \mathrm{~N} 315,50 \mathrm{~cm}^{3}$, K2N0 $11,33 \mathrm{~cm}^{3}, \mathrm{~K} 2 \mathrm{~N} 216,00 \mathrm{~cm}^{3}$ dan K2N3 $14,33 \mathrm{~cm}^{3}$.

Menurut Kumalasari dan Wulandani (2009), sifat-sifat tanah dan ketersediaan unsur hara menentukan pertumbuhan dan perkembangan perakaran tanaman. Prihahstanti (2010), sifat medium tanah yang baik akan mampu meningkatkan sebaran, pemanjangan dan kekompakan perakaran tanaman sehingga serapan hara serta pembentukkan asimilat menjadi tinggi yang kemudian dimanfaatkan kembali oleh akar tanaman untuk memacu pertumbuhan dan perkembangan perakaran agar lebih baik.

Menurut Susilawati dan Bastoni (2005), sebaran, pemanjangan dan jumlah serta juga akan mempengaruhi peningkatan volume akar tanaman. Menurut Karuseng dan Hamzah (2011), unsur hara, air dan ketersediaannya akan mempengaruhi proses pertumbuhan dan perkembangan perakaran tanaman. Semakin baik dan seimbang jumlah ketersediaan hara maka perakaran tanaman akan tumbuh dan berkembang dengan baik.

\section{Jumlah Anakan}

Hasil pengamatan terhadap Jumlah Anakan setelah dilakukan analisis ragam menunjukkan bahwa pengaruh interaksi maupun pengaruh utama pemberian pupuk Kascing dan NPK Mutiara 16:16:16 
memberikan pengaruh nyata terhadap Jumlah Anakan seledri. Rerata hasil pengamatan Jumlah Anakan setelah dilakukan uji beda nyata jujur $(\mathrm{BNJ})$ pada taraf $5 \%$ dapat dilihat pada tabel 4.

Tabel 4. Rerata Jumlah Anakan tanaman Seledri dengan pemberian pupuk Kascing dan NPK Mutiara 16:16:16.

\begin{tabular}{|c|c|c|c|c|c|}
\hline \multirow{2}{*}{$\begin{array}{c}\text { Pupuk } \\
\text { Kascing } \\
\text { (g/tanaman) }\end{array}$} & \multicolumn{4}{|c|}{ Pupuk NPK Mutiara 16:16:16 (g/tanaman) } & \multirow[b]{2}{*}{ Rerata } \\
\hline & N0 & N1 & $\mathrm{N} 2$ & N3 & \\
\hline $\mathrm{K} 0$ & $2,33 \mathrm{c}$ & $2,33 \mathrm{c}$ & $3,50 \mathrm{bc}$ & $3,50 \mathrm{bc}$ & $2,92 \mathrm{~b}$ \\
\hline K1 & $2,67 \mathrm{c}$ & $2,50 \mathrm{c}$ & $3,67 \mathrm{~b}$ & $3,67 \mathrm{~b}$ & $3,13 \mathrm{~b}$ \\
\hline K2 & $2,83 \mathrm{bc}$ & $2,50 \mathrm{c}$ & $2,83 \mathrm{bc}$ & $4,33 \mathrm{ab}$ & $3,13 \mathrm{~b}$ \\
\hline K3 & $2,83 \mathrm{bc}$ & $3,00 \mathrm{bc}$ & $4,33 \mathrm{ab}$ & $4,83 \mathrm{a}$ & $3,75 \mathrm{a}$ \\
\hline Rerata & $2,67 \mathrm{~b}$ & $2,58 \mathrm{~b}$ & $3,58 \mathrm{a}$ & $4,08 \mathrm{a}$ & \\
\hline $\mathrm{KK}=12,64 \%$ & & $=0,90$ & $\mathrm{BNJ}$ & 0,45 & \\
\hline
\end{tabular}

Berdasarkan data pada tabel 4, menunjukkan bahwa secara interaksi pemberian Pupuk Kascing dan NPK Mutiara 16:16:16 berpengaruh nyata terhadap jumlah anakan, dimana perlakuan terbaik K3N3 yaitu 4,83 tidak berbeda nyata dengan perlakuan K2N3 dan K3N2 namun berbeda nyata dengan perlakuan lainnya dimana tinggi tanama terendah terdapat pada perlakuan K0N0 yaitu 2,33 yang tidak berbeda nyata dengan $\mathrm{K} 1 \mathrm{~N} 0$, K0N2，K0N3，K1N0，K1N1，K2N0，K2N1, K2N2, K3N0 dan K3N1.

Penambahan jumlah anakan yang stabil, diduga tanaman dalam masa generatif. Menurut Abudullah et.al (2016) jumlah anakan maksimum tercapai pada umur 50-70 HST kemudian anakan yang terbentuk setelah mencapai batas maksimum akan berkurang bahkan terhenti karena pertumbuhannya yang melemah. Selain hal tersebutBerdasarkan hasil penelitian Hasrizart (2008) bahwa,kemampuan tanaman dalam berfotosintesis akan berpengaruh pada pertumbuhantanaman yang lebih baik sehingga mampu menghasilkan jumlah anakan yang lebih banyak.

Menurut Schilletter dan Richey (1999) karbohidrat akan terakumulasi ketika pertumbuhan vegetatif tanaman atau bagian dari tanaman terhambatsehingga karbohidrat yang dihasilkan dari proses fotosintesis tersebut dapat 31digunakan untuk pertumbuhan organorgan generatif. Pertumbuhan anakan yang tinggi pada fase generatif tanaman akan menyebabkan fotosintat terbagi antara pertumbuhan generatif dan vegetatif sehingga pertumbuhan generatif tidak optimal.

\section{Jumlah Pelepah}

Hasil pengamatan terhadap Jumlah Pelepah setelah dilakukan analisis ragam menunjukkan bahwa pengaruh interaksi maupun pengaruh utama pemberian pupuk Kascing dan NPK Mutiara 16:16:16 memberikan pengaruh nyata terhadap Jumlah Pelepah seledri. Rerata hasil pengamatan Jumlah Pelepah setelah dilakukan uji beda nyata jujur (BNJ) pada taraf 5\% dapat dilihat pada tabel 5 .

Berdasarkan data pada tabel 5, menunjukkan bahwa secara interaksi pemberian Pupuk Kascing dan NPK Mutiara 16:16:16 berpengaruh nyata terhadap jumlah pelepah, dimana perlakuan terbaik K3N3 yaitu 52,33 tidak berbeda nyata dengan perlakuan K3N2 namun berbeda nyata dengan perlakuan lainnya dimana tinggi tanama terendah terdapat pada perlakuan K0N0 yaitu 12,67 yang tidak berbeda nyata dengan K0N1.

Prasetya, dkk (2009) menjelaskan bahwa nitrogen bermanfaat untuk pertumbuhan vegetatif tanaman yaitu pembentukkan sel-sel baru seperti daun, cabang dan mengganti sel-sel rusak. Mengemukakan apabila tanaman kekurangan unsur $\mathrm{N}$ tanaman memperlihatkan pertumbuhan yang kerdil. 
Tabel 5. Rerata Jumlah Pelepah tanaman Seledri dengan pemberian pupuk Kascing dan NPK Mutiara 16:16:16.

\begin{tabular}{cccccc}
\hline \multirow{2}{*}{$\begin{array}{c}\text { Pupuk } \\
\text { Kascing } \\
\text { (g/tanaman })\end{array}$} & \multicolumn{3}{c}{ Pupuk NPK Mutiara 16:16:16 (g/tanaman) } & \multirow{2}{*}{ Rerata } \\
\cline { 2 - 4 } & $\mathrm{N} 0$ & $\mathrm{~N} 1$ & $\mathrm{~N} 2$ & $\mathrm{~N} 3$ & \\
\hline K0 & $12,67 \mathrm{k}$ & $13,17 \mathrm{k}$ & $15,33 \mathrm{j}$ & $17,17 \mathrm{i}$ & $14,58 \mathrm{~d}$ \\
K1 & $16,67 \mathrm{ij}$ & $18,17 \mathrm{hi}$ & $19,17 \mathrm{~h}$ & $19,17 \mathrm{~h}$ & $18,29 \mathrm{c}$ \\
K2 & $20,83 \mathrm{gh}$ & $21,33 \mathrm{~g}$ & $25,17 \mathrm{e}$ & $25,17 \mathrm{e}$ & $22,63 \mathrm{~b}$ \\
K3 & $32,33 \mathrm{~d}$ & $36,00 \mathrm{c}$ & $52,33 \mathrm{a}$ & $52,33 \mathrm{a}$ & $40,54 \mathrm{a}$ \\
\hline Rerata & $20,63 \mathrm{~d}$ & $22,17 \mathrm{c}$ & $24,79 \mathrm{~b}$ & $28,46 \mathrm{a}$ & \\
\hline
\end{tabular}

$\mathrm{KK}=3,63 \% \quad \mathrm{BNJ} \mathrm{KN}=1,78 \quad$ BNJ K \& N =0,89

Angka-angka pada baris dan kolom yang diikuti oleh huruf kecil yang sama tidak berbeda nyata menurut uji lanjut BNJ pada taraf $5 \%$.

\section{Berat Basah Per Tanaman (g)}

Hasil pengamatan terhadap Berta Basah Per Tanaman setelah dilakukan analisis ragam menunjukkan bahwa pengaruh interaksi maupun pengaruh utama pemberian pupuk
Kascing dan NPK Mutiara 16:16:16 memberikan pengaruh nyata terhadap Berat Basah Per Tanaman seledri. Rerata hasil pengamatan Berat Basah Per Tanaman setelah dilakukan uji beda nyata jujur (BNJ) pada taraf $5 \%$ dapat dilihat pada tabel 6 .

Tabel 6. Rerata Berat Basah Per Tanaman (g) pada tanaman Seledri dengan pemberian pupuk Kascing dan NPK Mutiara 16:16:16.

\begin{tabular}{|c|c|c|c|c|c|}
\hline \multirow{2}{*}{$\begin{array}{c}\text { Pupuk } \\
\text { Kascing } \\
\text { (g/tanaman) }\end{array}$} & \multicolumn{4}{|c|}{ Pupuk NPK Mutiara 16:16:16 (g/tanaman) } & \multirow{2}{*}{ Rerata } \\
\hline & No & N1 & $\mathrm{N} 2$ & N3 & \\
\hline $\mathrm{K} 0$ & $27,57 \mathrm{k}$ & $30,60 \mathrm{k}$ & $34,58 \mathrm{j}$ & $41,47 \mathrm{i}$ & $33,55 \mathrm{~d}$ \\
\hline K1 & $41,02 \mathrm{i}$ & $45,13 \mathrm{~h}$ & $46,00 \mathrm{~h}$ & $48,28 \mathrm{~h}$ & $45,11 \mathrm{c}$ \\
\hline $\mathrm{K} 2$ & $48,25 \mathrm{~h}$ & $51,75 \mathrm{~g}$ & $57,08 \mathrm{f}$ & $61,17 \mathrm{e}$ & $54,56 \mathrm{~b}$ \\
\hline $\mathrm{K} 3$ & $73,80 \mathrm{~d}$ & $90,85 \mathrm{c}$ & $98,33 \mathrm{~b}$ & $105,02 \mathrm{a}$ & $92,00 \mathrm{a}$ \\
\hline Rerata & $47,66 \mathrm{~d}$ & $54,58 \mathrm{c}$ & $59,00 \mathrm{~b}$ & $63,98 \mathrm{a}$ & \\
\hline
\end{tabular}

$\mathrm{KK}=2,74 \% \quad \mathrm{BNJ} \mathrm{KN}=3,41 \quad$ BNJ K \& N $=1,70$

Angka-angka pada baris dan kolom yang diikuti oleh huruf kecil yang sama tidak berbeda nyata menurut uji lanjut $\mathrm{BNJ}$ pada taraf $5 \%$.

Berdasarkan data pada tabel 6, menunjukkan bahwa secara interaksi pemberian Pupuk Kascing dan NPK Mutiara 16:16:16 berpengaruh nyata terhadap Berat Basah Per Tanaman pada umur dimana perlakuan terbaik K3N3 yaitu 105,02 g berbeda nyata dengan perlakuan lainnya. Sedangkan perlakuan terendah terdapat pada K0N0 yaitu 27,57 g yang tidak berbeda nyata dengan perlakuan K0N1.

Menurut Darmanti, dkk (2009), pertumbuhan dan perkembangan batang tanaman mengacu pada tahap akhir dari perkembangan vegetatif, meliputi pembesaran sel, pemanjangan sel, akumulasi asimilatif yang muncul ari efek pemenuhan hara dan air. Paat (2011), seluruh jenis unsur hara maupun air memegang peranan penting pada tanaman.
Pemenuhan jenis dan jumlah hara yang baik akan memberikan peran baik dalam meningkatkan proses fisiologi dan morfologis tubuh tanaman sehingga dapat memacu peningkatan berat keseluruh bagian tanaman. Menurut Nurhidayah (2005) biomassa atau berat seluruh bagian tanaman merupakan hasil pemenuhan unsur hara dan air yang di dukung oleh tinggi, jumlah dan ukuran organ-organ tanaman lainnya. Rosyadi (2009), penyerapan unsur nitrogen dan air yang baik karena kondisi tanaman mampu menyediakan seluruh jenis unsur hara akan menyebabkan dinding sel lebih sukulen sehingga kadar air akan meningkat dan biomassa tanaman pada keadaan segar.

Berat basah per tanaman seledri pada perlakuan K0NO (kontrol) yang menunjukkan hasil paling rendah dari perlakuan lainnya diduga karena tidak dilakukannya pemberian 
pupuk Kascing dan NPK Mutiara 16:16:16 menyebabkan tanaman seledri mengalami kekurangan unsur hara sehingga pertumbuhan organ vegetatif seperti akar, batang dan translokasi asimilat dan penyerapan terhambat. Menurut Wiro Admojo dkk (2001), defisien unsur hara akan menurunkan produktifitas tanaman dan akan ditandai dengan rendahnya hasil produksi yang dihasilkan pada tanaman tersebut. Hidayat (2010) dalam Usman (2013), hasil suatu tanaman dibatasi oleh kekurangan unsur hara, jika terjadi kekurangan unsur hara satu atau lebih unsur hara, maka pembentukkan dan translokasi asimilat akan terganggu. Marsono dan Sigit (2002), menyatakan terganggunya pembentukkan dan translokasi asimilat menyebabkan pertumbuhan organ tanaman terhambat sehingga biomassa tanaman menjadi rendah. Menurut Dwijoseputro (2002) dam Wahyudi (2004), kekurangan unsur haramenyebabkan terganggunya translokasi asimilat sehingga terjadinya penimbunan asimilat pada jaringan tanaman dan dalam jangka waktu tertentu jaringan tersebut akan mengalami penebalan sehingga bobot basa tanaman menjadi rendah.

\section{Umur Panen (HST)}

Hasil pengamatan umur panen seledri setelah di analisis ragam menunjukkan bahwa interaksi maupun pengaruh utama pupuk Kascing dan NPK Mutiara 16:16:16 tidak berpengaruh nyata terhadap umur panen tanaman seledri, oleh sebab itu tidak dilakukan uji lanjut BNJ. Rerata umur panen dapat dilihat pada tabel 7.

Tabel 7. Rerata Umur Panen pada tanaman Seledri dengan pemberian pupuk Kascing dan NPK Mutiara 16:16:16.

\begin{tabular}{|c|c|c|}
\hline Pupuk & & PK Mutiara 1 \\
\hline (g/tanaman) & N0 & N1 \\
\hline K0 & 78,00 & 78,00 \\
\hline K1 & 78,00 & 78,00 \\
\hline K2 & 78,00 & 78,00 \\
\hline K3 & 78,00 & 78,00 \\
\hline Rerata & 78,00 & 78,00 \\
\hline $\begin{array}{l}\text { Angka-angka pa } \\
\text { pada taraf 5\%. }\end{array}$ & dan kol & diikuti oleh $h$ \\
\hline $\begin{array}{l}\text { Berdasa } \\
\text { menunjukkan } \\
\text { pengaruh uta } \\
\text { Mutiara 16:1 } \\
\text { terhadap um } \\
\text { diperoleh sesu } \\
\pm 80 \text { HST, in } \\
\text { seperti suhu se }\end{array}$ & $\begin{array}{l}\text { data } \\
\text { a secar } \\
\text { pupuk } \\
\text { tidak } \\
\text { nen se } \\
\text { kripsi t } \\
\text { renakan }\end{array}$ & $\begin{array}{l}\text { tabel } 7, \\
\text { aksi maupun } \\
\text { dan NPK } \\
\text { garuh nyata } \\
\text { Jmur panen } \\
\text { seledri yaitu } \\
\text { i lingkungan } \\
\text { tersebut. }\end{array}$ \\
\hline
\end{tabular}

\section{KESIMPULAN}

Dari hasil penelitian yang telah dilakukan dapat diambil kesimpulan sebagai berikut:

1. Interaksi pupuk Kascing dan NPK Mutiara 16:16:16 memberikan pengaruh nyata terhadap tinggi tanaman dari ke dua sampai minggu ke tujuh, laju pertumbuhan relatif pada minggu pertama, volume akar, jumlah anakan, jumlah pelepah dan berat basah per tanaman. Perlakuan terbaik adalah K3N3 (pupuk Kascing K3 = 100 g/polybag dan
NPK Mutiara 16:16:16 N3 = 2,4 $\mathrm{g} /$ polybag), namun tidak berpengaruh nyata terhadap umur panen.

2. Pengaruh utama pemberian pupuk Kascing berpengaruh nyata terhadap tinggi tanaman, laju pertumbuhan relatif, volume akar, jumlah anakan, jumlah pelepah dan berat basah pertanaman, dengan perlakuan terbaik adalah K3 (pupuk Kascing 100 g/polybag).

3. Pengaruh utama pemberian NPK Mutiara 16:16:16 berpengaruh nyata terhadap tinggi tanaman, laju pertumbuhan relatif, volume akar, jumlah anakan, jumlah pelepah, dan berat basah pertanaman, dimana perlakuan terbaik adalah N3 (NPK Mutiara 16:16:16 $2,4 \mathrm{~g} /$ polybag). 


\section{DAFTAR PUSTAKA}

Abdullah, Mikrajudin. (2016). Fisika Dasari1. Bandung: ITB.

Anonimus, 2000. Pupuk NPK Mutiara (16-1616). PT Meroke Tetap Jaya. Skripsi Fakultas pertanian Universitas Islam Riau. Pekanbaru.

Agustina, L. 2004. Dasar Nutrisi Tanaman. Jakarta : PT Rineka Cipta.

2009. Teknologi Budiday Seledri Dataran Rendah. BPTP Jambi. Jalan Samarinda, Paal Lima, Kota Baru, Jambi. Diperoleh dari www//http:jambi.litbang.deptan.gi.id.

Dalimartha, S. 2000. Atlas Tumbuhan Obat Jilid Ke-2. Trubus Agriwidya. Jakarta.

Darmanti, S. 2009. Struktur dan Perkembangan Daun Acalypha indica L. yang Diperlakukan dengan Kombinasi IAA dan GA pada Konsentrasi yang Berbeda. Bioma. 11 (1) : 40 - 45.

Departemen Kesehatan RI. 2000. Tanaman Seledri. Departemen Kesehatan Republik Indonesia. Jakarta.

Dinas Pertanian dan Tanaman Pangan Provinsi Riau. 2011. Budidaya Seledri.

Hamzah, B\& Nurdin (2011). Belajar dengan Pendekatan PAILKEM. Jakarta:

PT Bumi Aksara

Hardjowigeno, S. 2003. Ilmu Tanah. Akademika Presindo. Jakarta.

Hayati, dkk. 2010. Pengaruh Suhu Pengeringan Terhadap Mutu Rosella Kering (Hibiscus sabdariffa). Program Studi Agroteknologi. Fakultas Pertanian. Universitas Syiah Kuala Darussalam. Banda Aceh. Jurnal.

Hasibuan, Malayu S.P, 2003, Manajemen Sumber Daya Manusia, Edisi Revisi, Bumi Aksara, Jakarta.

Hendri, S. N dan Rusnadi, D., 2009. Kandungan Klorofil dan Pertumbuhan Kacang Panjang (Vigna sinesis) Pada Tingkat Penyediaan Air yang Berbeda. Jurnal Sains dan Matematika 17 (3) : 145-150.

Hendri, M., N. Napitupulu dan A. P, Sujalu. 2015. Pengaruh Pupuk Kandang Sapi dan Pupuk NPK MutiaraTerhadap Pertumbuhan dan Hasil TanamanTerung Ungu (Solanum melongena L.). Jurnal AGRIFOR. Fakultas Pertanian
Universitas 17 Agustus 1945. Samarinda. 14 (2): 213-215.

Hermawan, E., 2005. Pengaaruh Pemupukan Nitrogen dan Fosfor Terhadap Pertumbuhan dan Produksi Tanaman Herba Seledri. Skripsi Fakultas Pertanian Institut Pertanian Bogor. Bogor.

Hidayat A.A., (2010). Metode Penelitian Kesehatan Paradigma. Kuantitatif, Jakarta: Heath Books.

Irmayani. 2013. Aplikasi Pupuk Daun Growmore dan Media Tanam Pada Tanaman Anthurium (Anthurium sp.). Agroteknologi Fakultas Pertanian Universitas Islam Riau. Pekanbaru.

Jedeng, I. W. 2011. Pengaruh Jenis dan Dosis Pupuk Organik Terhadap Pertumbuhan dan Hasil Ubi Jalar Var. Lokal Ungu. Thesis Program Pasca Sarjana. Universitas Udayana. Denpasar. Bali.

Kartini, N.L. 2007. Cacing Tanah, Indikator Kesuburan Tanah. Fakultas Pertanian Universitas Sumatera Utara. Medan.

Krishnawati, D. 2003. Pengaruh Pemberian Pupuk Kascing Terhadap Pertumbuhan Vegetatif Tanaman Kentang (Solanum tuberosum). KAPPA, 4:9-12

Lakitan, B. 1996. Dasar-Dasar Fisiologi Tumbuhan. PT Raja Grafindo: Jakarta.

Lingga P dan Marsono. 2007. Petunjuk Penggunaan pupuk. Penebar Swadaya Jakarta.

Listyari, B. P. 2006. Analisis Diosman dan Protein Tanaman Seledri (Apium graviolens $L$.) dari Daerah Cipanas dan Ciwidey. Skripsi Program Studi Biokimia Fakultas Matematika dan Ilmu Pengetahuan Alam Institut Pertanian Bogor. Bogor.

Marsono, P.S. 2005. Pupuk Akar dan Jenis Aplikasi. Penebar Swadaya: Jakarta.

Marsono dan Sigit P. 2001. Pupuk Akar, Jenis dan Aplikasi. Jakarta : Penebar Swadaya.

Martodenso dan Suryanto, M.A. 2001. Terobosan Teknologi Pemupukan dan Era Pertanian Organik. Penerbit Kanisius. Yogyakarta.

Mulat, T. 2003. Membuat dan Memanfaatkan Kascing Pupuk Organik Berkualitas. Agromedia Pustaka. Jakarta.

Mulyani Sutedjo, M. 2008. Pupuk Dan Cara Pemupukan. Rineka Cipta. 
Jakarta.Fakultas Pertanian Universitas Islam Riau. Pekanbaru.

Novizan. 2005. Petunjuk Pemupukan Yang Efektif. Agromedia Pustaka. Jakarta.

Nugroho, B. 2004. Petunjuk Penggunaan Pupuk Organik. Jurnal Ilmu Pertanian 1 (3) : 3849. Program Studi Budidaya Pertanian Departemen Agroteknologi Fakultas Pertanian Institut Pertanian Bogor. Bogor.

Nurchyati, Y. 2006. Produksi gosipol menggunakan kultur akar berambut Gossypium hirsutum L, Berkala Ilmiah Biologi 5(1):51-56

Nurhidayah,A., 2005. Pengaruh Sanitasi dan Masa Panen Terhadap Kandungan Diomin Pada Tanaman Seledri.Fakultas Matematika dan Ilmu Pengetahuan Alam Institut Pertanian Bogor. Bogor.

Rino, N. 2009. Pengaruh Pemberian Pupuk Cair Organik dan Pupuk Kascing Terhadap Tanaman Kakao, Prey Nursery. Skripsi. Universitas Sumatra Utara. Medan.

Rosmawaty, T., 2009. Pengaruh Pemberian Bat. Guano dan Pramigo Terhadap Pertumbuhan dan Hasil Seledri di Dalam Polybag. Jurnal Dinamika Pertanian 27 (2) : 163-170.

Sarti, M., Rosmawati dan Sulhaswardi. 2014. Uji Limbah Padat Kelapa Sawit dan Pupuk NPK 16:16:16 Pada Tanaman Rosella (Hibiscus sabdariffa L.). Jurnal Dinamika Pertanian 29 (1) : 27-36. Fakultas Pertanian Universitas Islam Riau.

Sanches, P. A. 1992. Properties and Management of Soil in the Tropics.

Simanjuntak, D. 2004. Manfaat Pupuk Organik Kascingdan Cendawan MikorizaArbuskula (CMA) pada Tanah dan Tanaman.Jurnal Penelitian Bidang Ilmu Pertanian. Universitas Sumatra Utara. Medan. 2(1) : 1-3.

Sinha, R.K., S. Herat, S. Agarwal, R. Asadi dan E. Carretero. 2002. Pengelolaan Lingkungan dan Pengelolaan Limbah: Studi Tindakan Cacing Tanah Elsinia foetida, Eudrilus euginae dan ekskavasi Perionyx pada Biodegradasi Beberapa Limbah Masyarakat di India dan Australia. Lingkungan. 22 (3): 233-240.

Sudiarto, B. 2001. Peranan Cacing Tanah dalam Pengolahan Sampah dan Sebagai Sumber
Pendapatan Masyarakat. Pusat Studi Cacing Tanah. Asosiasi Kultur Vermi Indonesia (AKVI). Jatinangor.

Sunarjono, 2003. Fisiologi Tanaman Budidaya. UI Press. Jakarta. 428 hal.

Susanto, R. 2005. Dasar-Dasar Ilmu Tanah. Kanisius. Jakarta. 67 hal.

Sutanto, R. 2002. Pertanian Organik. Kanisius. Yogyakarta

Sutikno, S. 2009. Belajar dan Pembelajaran. Prospect. Bandung, 2009.

Sutedjo, M. M. 2008. Pupuk dan Cara Pemupukan. Jakarta : Rineka Cipta

Winarso, S. 2005. KesuburanTanah: Dasar Kesehatan dan Kualitas Tanah. Gavamedia. Jogjakarta. 269 hal. 
